\title{
Return of Japan? Transformation of the balance of power in the Asian theatre
}

\author{
Pawel Pasierbiak \\ Department of World Economy and European Integration, \\ Faculty of Economics, \\ Maria Curie-Skelodowska University, \\ Poland \\ pawel.pasierbiak@umcs.pl \\ ORCID 0000-0002-0885-1462
}

Bruce A. Kibler*

Dablkemper School of Business,

Gannon University,

United States

kibler006@gannon.edu

ORCID 0000-0002-8187-672X

* Corresponding Author

Abstract. Since in the early seventies after the Japanese economy had been rebuilt from the destruction of WWII and had become competitive based on preeminent manufacturing and infrastructure, high technological advancement, networked production and distribution networks, Japan has been considered the leading power base in Asia from the early 1970's. After an initial competitive phase with the US, Japan and the U.S. have maintained a long standing economic and political relationship. However, the continued outsourcing of US manufacturing to low cost countries, specifically to China, an evolving balance of power can be clearly observed since China's opening up to foreign trade and investment and implementing free-market reforms in 1979. This article examines the economic developments over the last two decades (2000-2019), coincident with China's joining the World Trade Organization (as well as the dot.com bubble and the 2008 Recession) and its rise in economic and political might to determine how Japan's role may develop in the future. The article begins with an examination of political power theory and moves to specific economic indicators over the time period in question (2000-2019) as well as drawing on current political and economic developments from the Belt and Road Initiative (BRI) to the lackluster Japanese economic growth and development and increase in debt/GDP. The text contrasts the US theoretical model (Kindleberger, Krasner \& Gilpin), which represents a field balanced by hegemonic stability, as opposed to the UK model 
(Cohen, Strange) which is based more on a framework of cooperation and a more theoretical examination of power. It is posited that national power has increasingly ceded to global corporate power (Stopford, Henley, Strange). Against this theoretical background the economic indicators of the region are examined from 2000-2019. The analysis carried out in the study is based on several research methods: a critical analysis of the literature, a descriptive method, and a method of inference based on statistical data. Trade and FDI flows in the region are presented and examined to make assumptions on the waxing or waning influence of the players. It was found that there is neither specific evidence that Japan will recede in relative importance nor garner increased relevance. Finally, there is an ensuing discussion of geopolitical factor which are analyzed within the current developmental context, which have the potential to greatly influence future economic and political power in the region, and beyond. Specific policy measures are beyond the scope of this paper.

Keywords: Balance of power theory, Japan, China, economic development, economic power, descriptive method

JEL Classification: F02, F10, F23

\section{INTRODUCTION}

Contemporary Asia commands a growing share in world production, international trade, and capital flows as are clearly shown later in this paper using specific tables. Japan's evolution as an economic leader in East Asia is key in understanding the emerging economic dynamics. Japan has been displaced from being the second largest world economy to third place. Production, trade, and capital flows became competition areas in a struggle for influence between the traditional leader (Japan) and the emerging center (China) and China has become predominant.

In November 2019 Ian Bremmer, well renowned in the fields of political science and political global risk, delivered a speech at the 2019 GZERO Summit in Tokyo (Bremmer, 2019). The topic of the speech was, "The End of the American International Order: What Comes Next?" The overall tenor of the speech was the decline of US preeminence in the world and the rise of powers that will be far more prevalent, especially China, in the Asian theater. Bremmer hypothesizes that Chinese influence emanating from many new initiatives such as the Belt and Road Initiative, can be ameliorated by a resurgence of Japanese influence in the region.

This study's primary goal is to answer the title question: is it possible for Japan to return to its traditional role as the region's most influential economy? The theoretical framework of the analysis is based on two leading schools of the international political economy, i.e., the American school emphasizing the role of the dominant entity (hegemon) and the British school, which emphasizes the importance of international cooperation and points to the weakening role of states and the increasing role of international enterprises.

In order to realize the goal of the study, the article is composed of a few sections. The introductory section, followed by a section describing the theoretical aspects of balance of power. The third section, elucidates the evolution of the economic and political aspects of Japan's role in East Asia. Section 4 summarizes some findings of the research. The final section is devoted to an overarching discussion.

To achieve the aim of the study, the methods of critical analysis of the subject literature, the method of statistical data analysis, and the descriptive method were applied. The time scope of the analysis covers 
the years 2000-2019. It was decided to specifically exclude any analysis concerning the effects of Covid. Although, this is a crucial factor in shaping the economic reality, the pandemic is not over yet and any firm conclusions are not possible at this juncture of time.

\section{THEORETICAL DEBATE}

The issue of the balance of power in the global and regional economy has attracted the attention of political scientists and economists for decades. As a result of the research undertaken after World War II, two leading research schools emerged within the international political economy: the American school with its concept of hegemonic stability, and the British school, with an idea based on the cooperation of the most important participants in the world economy. According to the American school, an order in the liberal international economic system can be secured by the presence of one dominant center, i.e., by the existence of a hegemon. Both political science scholars such as R. Gilpin (1975) and S. Krasner (1976), but also economists, including C. Kindleberger (1973), concluded that only the dominant state could create and maintain order in the global economy. The state assumes leadership functions and undertakes actions aimed at restoring the balance in the event of its imbalance. R. Keohane (1980) described this concept as the hegemonic stability theory. This theory binds political and economic factors and explains the changes taking place in the architecture of the international system. The concept has been interpreted and developed by a number of scholars (see, among others, Deudney \& Ikenberry, 1999; Gilpin, 1981, 2001; Keohane, 1984; Snidal, 1985). The theory of hegemonic stability has also been used in research on the specificity of Chinese domination in Asia (the Kang model). Generally speaking, this model attempts to confirm the theory of hegemonic stability within the Asian theater. According to its author, when China was weak, it usually led to chaos in Asia, while when it was strong and stable, an order was preserved (Kang, 2003, 2007, pp. 24 25).

The British school of the international political economy stands in opposition to the American school and the concept of hegemonic stability (Cohen, 2007). The views of its representatives have evolved in the direction of searching for the best solutions within the framework of cooperation between the most important participants of the global economy. For S. Strange, the leading representative of the school, economic factors, not political ones, are responsible for changes in the conditions in which relations between the most important entities of the world economy develop (Strange, 1987). In her opinion, a multidimensional structural power (in the dimensions of security, production, finance, and knowledge) to a greater extent than the relational force (the ability of country A to make country B carry out a specific activity) determines the results of the competition between states. The use of hegemonic structural power in a way that destroys international order and cooperation is an important factor for the economic instability of the international system (Strange, 1994). In subsequent works, the author develops considerations regarding the change in the structure of global economic entities that have a crucial impact on the balance of the international economic system. The institution of the state is losing its importance, and corporations operating in international business begin to play a more significant role (Stopford, Strange, \& Henley, 1991; Strange, 1998).

Following the debate, it is impossible not to get the impression that in today's reality, there exists a system that is defined on the one hand by the relations between states (governments), and on the other hand, by increasingly more assertive micro-level entities (corporations). Corporations interests span across multiple countries and regions and have the ability to strongly exert their influence across a wide geographic area and across multiple political, economic and social systems. The first aspect clearly shows that political, military, economic, and soft power is still used by the most important states of the system in order to maintain their hegemonic position. Nevertheless, all this is happening under the auspices of the increasing 
interdependence of states and the growing role of international politics, which mitigates the role of an individual country, especially small or medium-sized. In the second aspect, it is clearly visible that non-state actors, including transnational corporations, increasingly shape the international balance of power. The combination of these two elements gives a more comprehensive picture of the contemporary concept of balance of power.

Nowadays, the balance of power can be defined as a multipolar or bipolar distribution of power within the existing international systems, with supranational entities being one of the key elements of such a system. Global or regional order is maintained by the equilibrium of powers among major states (Ikenberry, 2016, p. 15). Without disregarding political power, it is worth pointing out that in the economic dimension, the strength of a country will be reflected in the degree of its involvement in international trade, flows of foreign direct investment, as well as in its participation in production networks. The connecting element here is the strength and scope of operation of multinational enterprises. On the other hand, this also gives multinational corporations power beyond the traditional concept of the nation state and they represent a power player on an entirely new level. One must also keep in mind that corporations, as we know them today, have been around also for a relatively short period of time but have amassed and exercised power well beyond singular national boundaries.

The regional order in East Asia is definitely in the state of transition. A rising China can be assessed as a threat to an equilibrium in the region (Beeson \& Murray, 2020, p. 4). According to the fundamental assertion of the balance-of-power theory, in response to a hegemonic threat, there should be an action balancing the system (Kaufman, Little, \& Wohlforth, 2007, p. 18). Thus, from that point of view, it is interesting to analyze the developments in East Asia. The appearance of a hegemon in the region (China) changes the status quo ante and causes a reaction from the participants of the system, including the traditional economic leader - Japan. It is an open question to what extent the country will undertake such actions and whether it can counterbalance the hegemonic threat to the system or accommodate to it. The contemporary situation is even more complicated, as, for decades, the order in the region was led and maintained by the United States. However, now the position of the analyzed country - Japan in the region is certainly transforming.

Lastly, the rise of social media and information flow are having an ever-increasing impact on perceptions of populations around the world. There could arise an analogous situation to that of the Cold War, during which the fall of the Iron Curtain was, to a great extent attributed to Western investment in propaganda into the Eastern Bloc countries, predominantly by the agency USAID. We have witnessed the Arab Spring being attributed to social media; can China continue its overpowering influence on its population within the framework of increased information. There are many layers of forces at work.

\section{EVOLUTION OF THE ECONOMIC AND POLITICAL POSITION OF JAPAN IN THE REGION}

\subsection{The economic strength of Japan}

There are many factors to be considered in contemplating the power relationships in the Asian theater, be they economic, political or military in nature. This section will begin with a look at some of the more common economic indices that are used in measuring and analyzing relative prosperity, attractiveness and power of a country. GDP, although an extremely flawed measure, is still one of the common ones used in examining the relative strength of an economy. As we can see from historical trends of the influential countries being examined, Japan's GDP has stagnated over several decades (see Figure 1). The Japanese stock market as represented by the benchmark Nikkei Average Index also reached a peak of about 40,000 
back in the late 1980s and has not reached that level again in the more than three decades since. The Shanghai Index, on the other hand has certainly had ups and down but a smoothed average has shown a steady increase over time as has the Dow Jones Index. Neither has stagnated as has the Nikkei Index. So, trading as well as overall transaction volumes in Japan are not keeping pace with the region, nor with their strongest external partner, the USA.

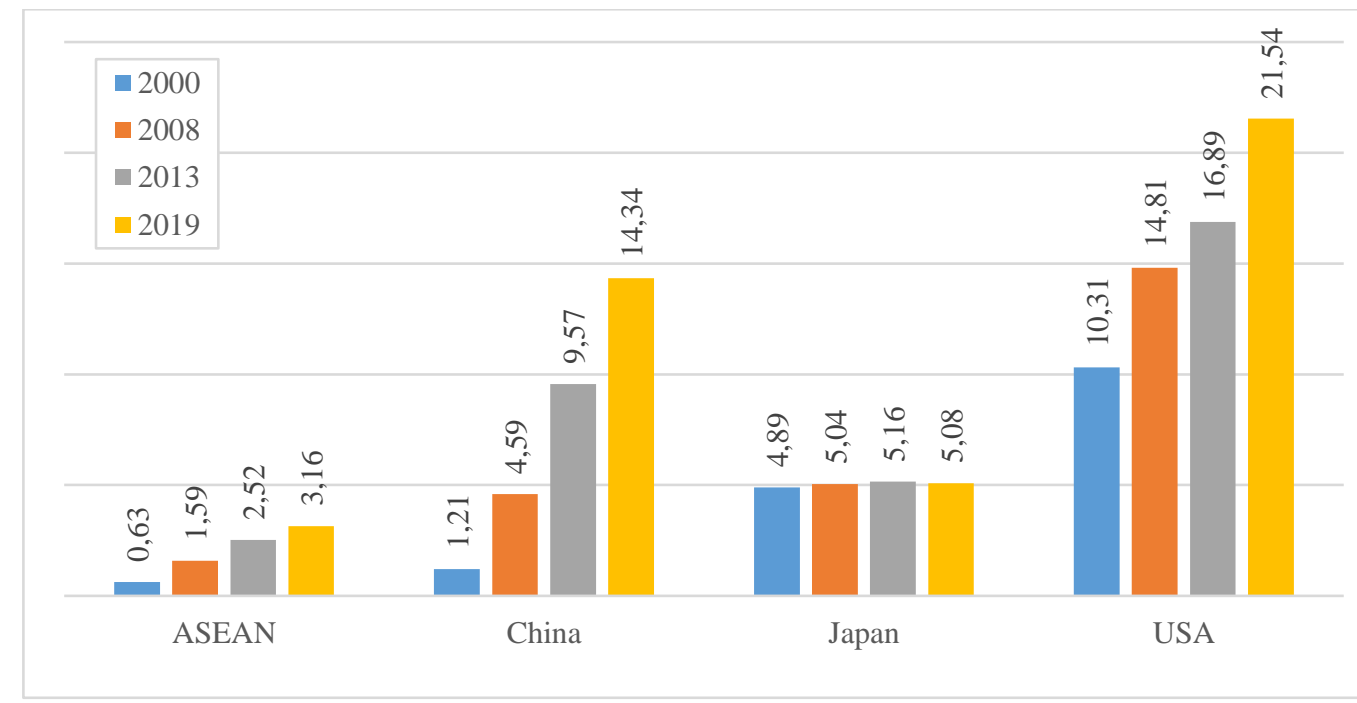

Figure 1. GDP value in selected economies, 2000-2019, USD trillion Source: (UNCTAD, 2021a).

In addition to GDP, debt and its ratio to GDP is becoming an increasingly important measure, especially when contrasted with stage of development of an economy and perhaps also structure. Structurally, Japan's economy is very different that of ASEAN, China or the USA. Japan's network of interconnected companies has long been a deterrent of FDI inflows, as we shall see. There has been an inability of foreign entities to have any meaningful share, or say in management within the Japanese economy. Although China cannot be said to allow foreign entities to have great impact on decision making from a corporate governance standpoint, foreign entities have been allowed to make considerable profits from investment in Chinese entities, or even wholly foreign owned entities in China, something non-existent from a Japanese ownership and control perspective.

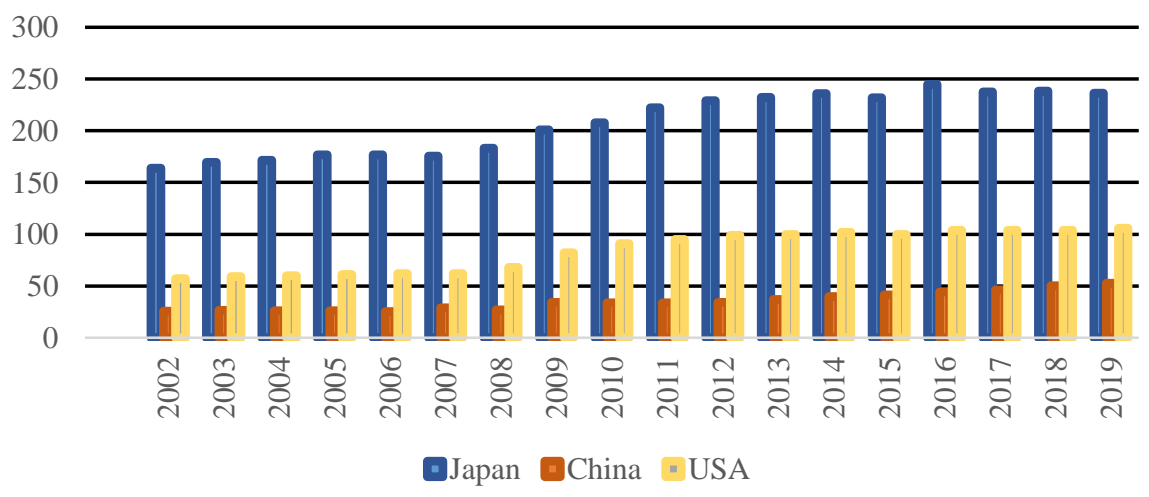

Figure 2. Debt to GDP ratios, 2002-2019, \% Source: (UNCTAD, 2021a). 
In the Figure 2 it becomes evident that economic development overall seems to be correlated to growing GDP to debt ratios. This has implications beyond this paper but suffice it to say that Japan has, with GDP as well as with stock market values, hit a plateau also with debt to GDP seemingly around $240 \%$, although currently a bit higher. So, we see that stock market values, GDP and debt/GDP seem to have found almost an equilibrium point for the time period being analyzed. That being said, there is also an overall correlation between economic development and rising debt ratios in other regions. In more developed western societies this can readily be correlated to the inverted population pyramid in which, for a myriad of reasons, populations are aging more rapidly than they are rejuvenating themselves with younger workers who can pay for the rising burden of an increasingly large older population. There is much written on the potential impact of immigration in such cases, especially in the EU and in the US. Again, although this topic is beyond the scope of this work, it is important to mention the lack of such cultural diversity and acceptance in Japan as well as in China, thereby limiting voluntary immigration as a solution mechanism.

Trade ties in Asia are another area where the evolution of the intra-regional balance of economic power can be observed. Its main characteristic is the waning position of Japan and the strengthening role of China. The global trend of increasing importance of Asian trade leads to a situation in which individual Asian countries increasingly rely on the internal Asian market, and consequently, traditional markets (e.g., North American or European) are losing their relative importance. ${ }^{1}$ Analyzing the structural changes of trade in East $\mathrm{Asia}^{2}$, one can identify characteristic trends that indicate a change in the role and importance of individual economies. Table 1 contains information on the change in individual countries' share in internal East Asian trade after 2000.

Table 1

Changes in shares of intra-East Asian merchandise trade in $21^{\text {st }}$ century

\begin{tabular}{|l|l|l|l|l|l|l|}
\hline & \multicolumn{2}{|l}{ Exports } & \multicolumn{2}{l|}{ Imports } & $\begin{array}{l}\text { Change } \\
\mathbf{2 0 1 9 / 2 0 0 0}\end{array}$ \\
\cline { 2 - 7 } & $\mathbf{2 0 0 0}$ & $\mathbf{2 0 1 9}$ & $\begin{array}{l}\text { Change } \\
\mathbf{2 0 1 9 / 2 0 0 0}\end{array}$ & $\mathbf{2 0 0 0}$ & $\mathbf{2 0 1 9}$ & $\mathbf{2 0 . 1}$ \\
\hline Brunei & $0.7 \%$ & $0.3 \%$ & -0.4 & $0.1 \%$ & $0.2 \%$ & $\mathbf{+ 0 . 1}$ \\
\hline Cambodia & $0.0 \%$ & $0.3 \%$ & $\mathbf{+ 0 . 2}$ & $0.2 \%$ & $0.9 \%$ & $\mathbf{+ 0 . 6}$ \\
\hline China & $15.7 \%$ & $33.3 \%$ & $\mathbf{+ 1 7 . 5}$ & $19.0 \%$ & $33.6 \%$ & $\mathbf{+ 1 4 . 6}$ \\
\hline Japdonesia & $7.3 \%$ & $5.0 \%$ & -2.2 & $4.9 \%$ & $5.6 \%$ & $\mathbf{+ 0 . 6}$ \\
\hline Korea & $29.0 \%$ & $15.5 \%$ & -13.5 & $27.3 \%$ & $15.3 \%$ & -11.9 \\
\hline Laos & $13.2 \%$ & $14.0 \%$ & $\mathbf{+ 0 . 8}$ & $12.7 \%$ & $10.6 \%$ & -2.1 \\
\hline Malaysia & $0.0 \%$ & $0.3 \%$ & $\mathbf{+ 0 . 2}$ & $0.1 \%$ & $0.3 \%$ & $\mathbf{+ 0 . 2}$ \\
\hline Myanmar & $10.1 \%$ & $6.8 \%$ & -3.3 & $9.0 \%$ & $5.8 \%$ & -3.1 \\
\hline Philippines & $0.1 \%$ & $0.6 \%$ & $\mathbf{+ 0 . 5}$ & $0.4 \%$ & $0.8 \%$ & $\mathbf{+ 0 . 4}$ \\
\hline Singapore & $3.0 \%$ & $1.9 \%$ & -1.1 & $3.4 \%$ & $3.9 \%$ & $\mathbf{+ 0 . 5}$ \\
\hline Thailand & $12.9 \%$ & $9.9 \%$ & -3.0 & $14.5 \%$ & $8.0 \%$ & -6.5 \\
\hline Viet Nam & $6.2 \%$ & $6.3 \%$ & $\mathbf{+ 0 . 1}$ & $6.4 \%$ & $6.4 \%$ & 0.0 \\
\hline
\end{tabular}

Source: Own calculations based on (UNCTAD, 2021b).

The data in Table 1 shows very clearly the changes in the geographical structure of intra-regional trade between 2000 and 2019. The largest exporters and importers in East Asia were China, Japan, and Korea,

${ }^{1}$ For example, in 2020, ASEAN became China's largest trading partner, ahead of the European Union and the United States (Dollar \& Stromseth, 2021).

${ }^{2}$ East Asia consists of 10 ASEAN member states (Brunei, Cambodia, Indonesia, Laos, Malaysia, Myanmar, the Philippines, Singapore, Thailand, Vietnam), as well as China, Japan, and South Korea. 
and to a lesser extent, Singapore, Thailand, and Malaysia. Nevertheless, since 2000, China's role has grown significantly. In 2019, the country's share in internal East Asian exports amounted to 33.3\%, which translates intoa17.5 p. p. increase since 2000. Similar changes can be observed for imports, where the numbers were $33.6 \%$ and 14.6 p. p., respectively. In terms of increase in share, the second country was Vietnam, which share grew by 4.2 p. p. (to $5.8 \%$ ) in internal exports, and by $6.7 \%$ (up to $8.7 \%$ ) in imports. The country with the highest decline in share was Japan. In 2000, the country accounted for $29 \%$ of East Asia's internal exports and $27.3 \%$ of imports. By 2019, the shares had decreased to $15.5 \%$ and $15.3 \%$, respectively, which meant a drop by as much as 13.5 p. p. in exports and 11.9 p. p. in imports.

Such transformations mean that Japan's intra-regional trade position is declining significantly, mainly in favor of its main rival, China. This tendency is also confirmed by the evolution of China and Japan's place in the ranking of trading partners of individual East Asian countries. The relevant data are presented in Table 2.

Table 2

Japan and China's rank as trade partners for East Asian economies in 2000 and 2019

\begin{tabular}{|c|c|c|c|c|c|c|c|c|c|c|c|c|}
\hline & \multicolumn{6}{|c|}{ Japan } & \multicolumn{6}{|c|}{ China } \\
\hline & \multicolumn{3}{|c|}{ Exports } & \multicolumn{3}{|c|}{ Imports } & \multicolumn{3}{|c|}{ Exports } & \multicolumn{3}{|c|}{ Imports } \\
\hline & 2000 & 2019 & Change & 2000 & 2019 & Change & 2000 & 2019 & Change & 2000 & 2019 & Change \\
\hline $\begin{array}{l}\text { Brunei } \\
\text { Darussalam }\end{array}$ & 1 & 1 & 0 & 3 & 4 & -1 & 5 & 6 & -1 & 5 & 1 & +4 \\
\hline Cambodia & 3 & 3 & 0 & 8 & 5 & +3 & 2 & 4 & +2 & 3 & 1 & +2 \\
\hline China & 1 & 1 & 0 & 1 & 2 & -1 & - & - & - & - & - & - \\
\hline Indonesia & 1 & 2 & -1 & 1 & 3 & -2 & 4 & 1 & +3 & 4 & 1 & +3 \\
\hline Japan & - & - & - & - & - & - & 2 & 1 & +1 & 1 & 1 & 0 \\
\hline Korea & 1 & 3 & -2 & 1 & 2 & $\begin{array}{l}-1 \\
\end{array}$ & 2 & 1 & +1 & 2 & 1 & +1 \\
\hline Laos & 3 & 4 & -1 & 5 & 4 & +1 & 4 & 2 & +2 & 3 & 2 & +1 \\
\hline Malaysia & 2 & 3 & -1 & 1 & 3 & +2 & 4 & 1 & +3 & 4 & 1 & +3 \\
\hline Myanmar & 3 & 3 & 0 & 6 & 7 & -1 & 2 & 1 & +1 & 2 & 1 & +1 \\
\hline Philippines & 1 & 1 & 0 & 1 & 2 & -1 & 6 & 2 & +4 & 6 & 1 & +5 \\
\hline Singapore & 2 & 4 & -2 & 1 & 3 & -2 & 3 & 1 & +2 & 4 & 1 & +3 \\
\hline Thailand & 1 & 2 & -2 & 1 & 2 & -1 & 3 & 1 & +2 & 3 & 1 & +2 \\
\hline Viet Nam & 1 & 2 & -2 & 2 & 3 & -1 & 2 & 1 & +1 & 4 & 1 & +3 \\
\hline
\end{tabular}

Source: Own calculations based on (UNCTAD, 2021b).

The data analysis clearly shows that between 2000 and 2019, China has become a key sales market, but most of all, a key supply market for almost all East Asian countries. During the period under review, China improved its position for each country (except Brunei), in some cases moving up five positions in the ranking. Japan's situation was completely different. The trade importance of this country for the East Asian partners, although still relatively high, has decisively weakened, especially on the import side. Japan, which in 2000 was China's first supply market in the region, in 2019 was classified as second, just behind South Korea. The presented analysis of the changes taking place clearly shows that Japan's role in intra-regional Asian trade is waning.

As is implied by the previous data and analysis, FDI inflows and outflows reinforce much of this. 


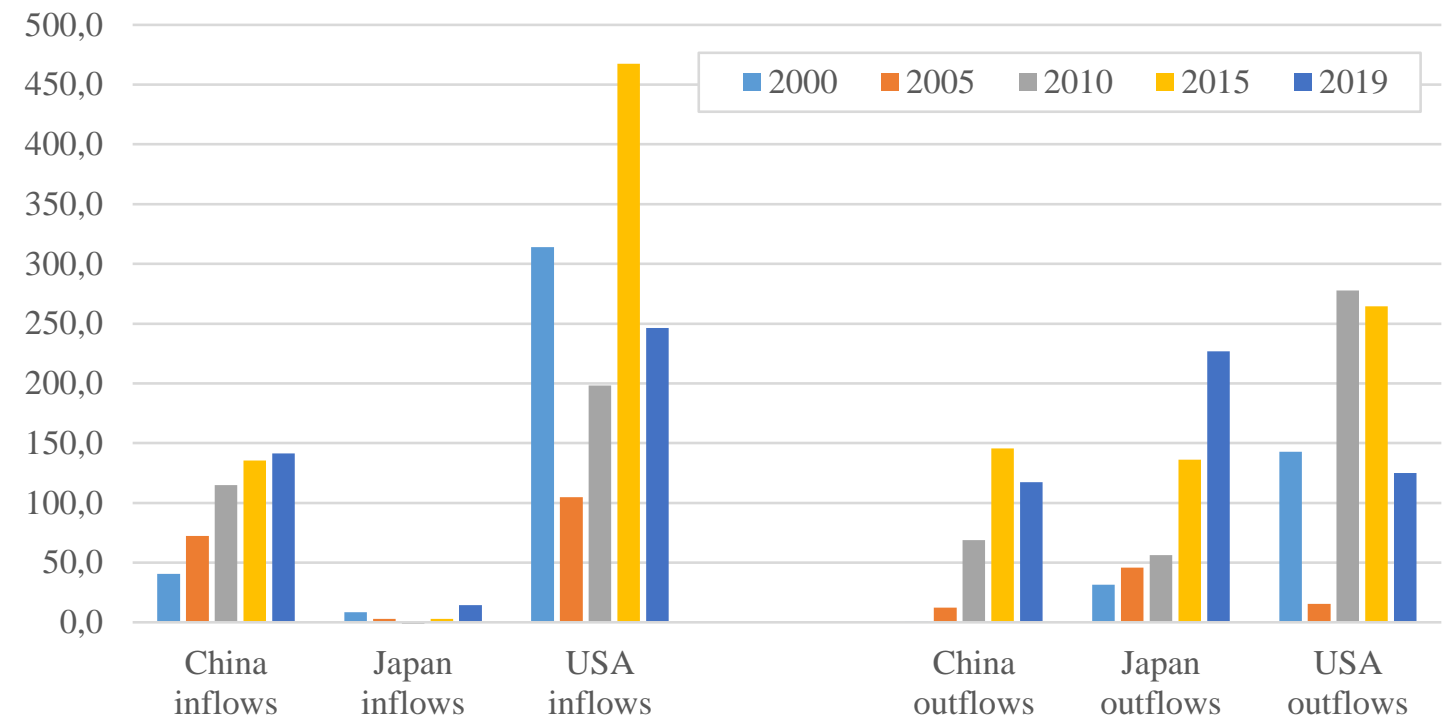

Figure 3. FDI flows in China, Japan, and the US in 2000, 2005, 2010, 2015 and 2019, USD billion Source: (UNCTAD, 2021a).

China has seen ever increasing FDI inflows based on sheer growth potential, whereas the US continues to attract FDI inflows due to the predictable stability of the economy and the power of its financial markets over time. The fall in inflows and outflows for the US correspond (but are not necessarily correlated) to President Trumps tax cuts as well as his initiated trade wars. As expected, Japan continually fails to attract any significant FDI inflows. This can readily be attributable to the factors mentioned above, especially the excluding nature of the Japanese economy. Firms do not tend to invest if they cannot achieve forms of control, even if merely strategic in nature. Japan continues to invest outwardly, which is essential in, at a minimum, retaining access to foreign supplies and markets.

From an economic indicator perspective, Japan's sole positive indicator is its continuous rise in FDI outflows. This is mitigated by extremely low economic growth and debt burden, which at present, will not be able to keep pace with Chinese growth and greater debt flexibility. Additionally, there appears to be significant potential from a structural perspective, i.e., allowing/encouraging foreign investment in the Japanese economy by loosening barriers to entry, specifically with respect to corporate governance aspects of ownership and control.

Looking beyond mere FDI statistics, Japan has long been considered to have great advantages in the area of networked production. Below (Table 3) are statistics from around the world on the value-added exports to various countries and regions for 2005 and 2015. Although more current numbers were not available (they are published with significant delay), it is clear that Japan still retains competitive advantage in the area of networked production in terms of value added. However, that competitive advantage is waning as other nations, especially China and ASEAN also continue to build their networked production and valueadded relationships. 
Value-added exports of selected economies, 2005 and 2015, in \%

\begin{tabular}{|c|c|c|c|c|c|c|c|c|c|c|c|c|c|c|c|c|c|c|c|c|}
\hline & \multicolumn{2}{|c|}{ Japan } & \multicolumn{2}{|c|}{ Korea } & \multicolumn{2}{|c|}{ China } & \multicolumn{2}{|c|}{$\begin{array}{l}\text { Hong } \\
\text { Kong }\end{array}$} & \multicolumn{2}{|c|}{ India } & \multicolumn{2}{|c|}{ Taipei } & \multicolumn{2}{|c|}{ ASEAN } & \multicolumn{2}{|c|}{ EU28 } & \multicolumn{2}{|c|}{ NAFTA } & \multicolumn{2}{|c|}{ RoW } \\
\hline & 2005 & 2015 & 2005 & 2015 & 2005 & 2015 & 2005 & & 2005 & & 2005 & 2015 & 2005 & 2015 & 2005 & 2015 & 2005 & 2015 & 2005 & 2015 \\
\hline Japan & 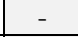 & - & & 4.1 & 12.3 & 19.0 & 0.8 & 0.7 & 0.8 & 1.1 & 3.1 & 2.3 & 10.7 & 12.2 & 16.2 & 13.3 & 16.2 & \begin{tabular}{|l|}
13.9 \\
\end{tabular} & 35.2 & \\
\hline 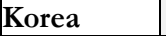 & & & & & 11.3 & 21.3 & 0.7 & 0.5 & \begin{tabular}{|l|}
0.9 \\
\end{tabular} & 1.3 & 3.4 & 3.4 & 8.0 & 7.8 & 12.5 & 13.0 & 14.1 & 12.2 & 30.7 & 31.5 \\
\hline & & & & & & 18.5 & 0.4 & 0.4 & \begin{tabular}{|l|}
1.2 \\
\end{tabular} & & 1.8 & & 3.2 & 4.2 & 23.3 & 19.9 & 22.3 & 22.9 & 26.9 & \\
\hline & & & & & 3.8 & 13.8 & 1.5 & 0.8 & \begin{tabular}{|l|}
2.0 \\
\end{tabular} & & & & 7.4 & 30.2 & 6.4 & 15.3 & 13.4 & 0.2 & 26.8 & \\
\hline & & & .1 & & & & 1.7 & 0.6 & 1. & & 0.5 & & 9.3 & 0.6 & 3.2 & .7 & 11.6 & 3.5 & 2.9 & \\
\hline & & & & & & & & & 2.4 & & & & 8.2 & & 26.9 & 7 & 13.1 & 4.1 & 17.6 & \\
\hline & & & & & & & 0.7 & 0.6 & & & & & 8.4 & & 16.6 & 12 & 9.2 & 10.3 & 52.7 & \\
\hline & 10.9 & & & & 8.4 & 19.5 & 0.8 & 1.0 & 2.5 & 2.6 & 2.1 & 2.0 & 16.4 & 16.3 & 13.2 & 10.1 & 9.7 & 8.3 & 31.8 & 27.3 \\
\hline & 9. & & & & 2. & & 1.4 & 1.7 & 2.9 & 4. & 1.7 & 2.3 & 9.7 & 11.1 & 18.9 & 17.1 & 15.1 & 15.4 & 35.8 & 28.9 \\
\hline & 2.2 & & & & 9.4 & 16.6 & 1.1 & 0.9 & \begin{tabular}{|l|} 
\\
\end{tabular} & 1.1 & & - & 8.7 & 11.1 & 10.8 & 8.6 & 12.1 & 9.1 & 28.4 & 35.7 \\
\hline & 8.5 & & & & 8.2 & 20.9 & 1.0 & 0.5 & 1.2 & $1 .($ & 3.5 & 2.9 & 11.4 & 11.4 & 11.5 & 10.2 & 10.2 & 8.4 & 30.5 & 27.7 \\
\hline & & & & & 13.6 & & 2.1 & 0.7 & 1.8 & 1. & & 4.6 & 15.4 & 10.4 & 9.8 & 8.2 & 5.1 & 6.4 & 22.7 & 17.5 \\
\hline & & & & & 9. & & 1.7 & 1.2 & \begin{tabular}{|l|}
2.1 \\
\end{tabular} & 3. & & 4.0 & & & 17.1 & \begin{tabular}{|l|}
14.3 \\
\end{tabular} & 16.3 & \begin{tabular}{|l|}
12.7 \\
\end{tabular} & 27.2 & 25.9 \\
\hline & & & & & & & 0.7 & 0.8 & 1.8 & 2. & & & 4.6 & & & & 22.5 & 24.7 & 53.2 & 45.6 \\
\hline NAFTA & 11.9 & 6.7 & 3.9 & 7.2 & 10.8 & 24.9 & 0.6 & \begin{tabular}{|l|}
0.5 \\
\end{tabular} & \begin{tabular}{|l|}
1.5 \\
\end{tabular} & 2.6 & 2.6 & 2.3 & 4.6 & 5.6 & 29.5 & 25.0 & & & 34.7 & \begin{tabular}{|l|}
28.4 \\
\end{tabular} \\
\hline
\end{tabular}

Note: Numbers show a share of the column economy in total foreign value added that is embodied in gross export of the row country.

Source: Own calculations based on (OECD-WTO, 2021).

\subsection{The political position of Japan}

Japan's political power in the Asian region is much more modest than the economic one. There are two main reasons for this situation: 1) Japan's military and economic expansionism initiated at the turn of the $19^{\text {th }}$ and $20^{\text {th }}$ centuries and its long-term effects, and 2) close cooperation with the United States in the field of security and economy after World War II.

Historical events related to the expansionism of Japan towards its neighbors (Korea, China; the attempt to create the Greater East Asia Co-Prosperity Sphere) and the pursuit of a historical policy characterized by the lack of recognition of one's faults make the perception of contemporary Japan by the countries of the region negative in many cases. This applies particularly to South Korea and China - the largest economies in the region (Harold, 2015). According to a study by the Pew Research Center, 63\% of Koreans had an unfavorable opinion of Japan (Pew Research Center, 2018, p. 19) and as many as 81\% of the Chinese (2016) (Pew Research Center, 2016, p. 2). At the same time, it is also worth mentioning that Japanese perception of China was even more unfavorable: in 2016, as many as 86\% of Japanese negatively assessed their neighbor. This shows a relatively high level of hostility between Japan and its neighbors, which is certainly not conducive to Japan's role as a political leader in the region (Zhao, 2004, p. 111). Complicated relations in the political sphere are transferred to the economy. One example is the escalation of hostile sentiment between Japan and South Korea in 2019. Claims by Koreans for injustices suffered from the Japanese during World War II and their rejection by Japan resulted in an open conflict between the countries, which manifested itself in the mutual boycott of the partner's products or the suspension by Japanese of deliveries of key components for goods exported by South Korea (Kim, 2019).

Difficult historical experiences are only one of the factors contributing to Japan's relatively low political position in the region. Another critical factor is a specific relation with the United States, which developed particularly intensively after World War II (Yoshimatsu, 2021, p. 23). The post-war occupation turned into a tight military and defense alliance between Japan and the United States (Yoshida doctrine). On the one hand, the United States became the guarantor of Japan's security; on the other hand, Japan supported the implementation of the United States' strategy in Asia with the goal to oppose the expansion of communism. 
Strong political and economic ties with the USA were and still are a priority for Japan, which was not (and is not) conducive to building a political position and partnership relations with countries in the region. In general, Japan was not very independent in its decisions, and even when there was a clear need to act for the benefit of the region, in the opinion of many Asian countries, Japan turned out to be excessively susceptible to the influence of the United States. ${ }^{3}$

Due to the disproportions between the political and economic, not to mention a soft dimension of power, Japan mainly used economic diplomacy to build its influence in the region. According to the theory, a country that does not have power in all its dimensions (political, economic, and cultural), i.e., is a onedimensional power, reduces its role in the international balance of power in the long run. It seems that this is a picture of contemporary Japan, which also today is trying to use its economic advantages in Asia, developing quite intensively trade relations and maintaining substantial capital and production ties with the countries of the region with a use of its transnational corporations.

The balance of power in Asia has evolved. At the beginning of the $21^{\text {st }}$ century, a new power emerged in the region. China, a permanent member of the UN Security Council, has shown high development dynamics since the early 1990s. The average GDP growth rate significantly exceeded the results achieved by Japan and other countries in the region, which in 2010 allowed China to overtake Japan in terms of GDP value. Japan increasingly had to take into account the economic strength of its neighbor. Moreover, China's power grew also in the political sphere. The country has changed the orientation of its policy from passive to active. It was revealed, among others, in promoting the creation of the Shanghai Cooperation Organization (SCO), increasing the country's activity in the Asia-Pacific Economic Cooperation (APEC), or in preparing a free trade agreement with ASEAN (the ASEAN-China Free Trade Area) (Yoshimatsu, 2021, p. 24).

From the point of view of Japan's political role in the region, an important aspect is the active policy of other actors, including ASEAN. This organization often situates itself as a promoter of regionalism in Asia, positioning itself as an active regional center. Thanks to ASEAN, the initiative of ASEAN Plus Three (plus China, Japan, Korea), ASEAN Regional Forum, Asia-Europe Meeting, and East Asia Summit has developed. It can be concluded that even though ASEAN is made up of relatively small countries, the impact of this entity in the region is quite significant, and it seems that 'ASEAN centrality' has to some extent been accepted by other countries, including Japan (Caballero-Anthony, 2014).

The conditions presented above justify the statement that although Japan's political role has never been high, today, additional factors are unlikely to allow for a significant strengthening of this country's importance in the region. Japan faces a dilemma: on the one hand, it has strong ties with the United States and will participate in initiatives undertaken by that country, and on the other hand, very strong economic ties with China force cooperation with its neighbor. There is no an easy way to resolve this dilemma.

\section{FINDINGS}

Revisiting Kindleberger's thesis of only a dominant state being able to create and maintain order vs. the Anglo-American view of hegemonic stability via cooperation, one is faced with a plethora of conflicting data and developments. The Chinese approach appears more based on economic advantage rather than cooperative relationships. As networked production becomes less of a competitive advantage, mostly due to the further development of other economies and nations, Japan power in the region, if based on

\footnotetext{
${ }^{3}$ For example, in the wake of Asian Financial Crisis, Japan proposed creation of Asian Monetary Fund as an institution supporting financial stabilization of the region during financial crises. Later Japan withdrew the initiative after negative opinion and opposition from the United States.
} 
normative views, will continue to wane. With no direct access to raw materials and the assumption of China's BRI success, Japan, from a production perspective, becomes completely reliant on economic gain of external entities, especially China, for their continued prosperity. How China may inevitably treat such entities in its value-chain, is yet to be seen in the future. However, drawing on observed trends, should China become the hegemonic power they would merely use Japan to increase its own economic power, thereby continually squeezing margins from the supply chain. With current debt levels in Japan, it remains to be seen to what extent continued borrowing would be able to compensate for a deterioration of Japanese wealth and power against this backdrop.

Of course, this is merely a singular potential scenario based on current developments and positioning. A major factor is the continued tensions between the US and China and the role Japan can and will play here. As a non-military entity, Japan will be relegated to predominantly watching the outcome. Choosing an incorrect "side" in any upcoming conflicts could prove disastrous. It appears that Japan's best course of action is to remain neutral, continue building technological and infrastructure advancements as well as economic and political allies to be best positioned for any outcome of the current tensions.

In the short term, one can find many current examples of positive reports for Japan. For example, in the recent article in Quartz (Hui, 2021) where Japan's strategy for regaining control of rare earth mineral supplies from China's over $90 \%$ chokehold just 10 years ago, thereby securing their ability to continue high value industrial production is extolled. Although the conclusion was that they have merely reduced supply risk on less than $50 \%$ of the supply. In Bloomberg's article (Nohara \& Takeo, 2021) it is stated, "Japan's record exports to Asia in March show external demand broadening beyond China and providing firmer support for the economy". But probably most important example comes from the Canadian Press (McGuirk, 2021), which describes the cancellation of a BRI infrastructure project in Australia, signaling potential trouble ahead in the implementation for BRI, as has also been reported in other sources for other geographic locations. Lastly, the article recently published by CNN's Brad Lendon (2021) about the biggest navy in the world which is the Chinese one. Although it would currently be catastrophic for China to deploy this new naval power against the likes of Australia, there are many smaller countries involved, or planned within the BRI which could be intimidated by force. In light of other articles speculating on China moving to integrate Taiwan in the not too distant future, the question arises as to how far will China go with this military might?

However, putting the issues of peak oil, continued dependence on China for most of their rare earth minerals, overall resource scarcity, whether it be nationalistically or economically driven, relative national debt and, in this authors' humble opinion, overall effects of climate change and pollution, are all aspects that do not bode well, but not just for Japan. Again, overall Japan's best strategy appears to be their ability to straddle global geopolitical stress points and remain an industrial powerhouse which can serve others. But these must also at some point be replaced.

All told, the authors cannot find suitable evidence to support Ian Bremmer's claim of a resurgent Japan. However, there is also no hard evidence that Japan's role is particularly threatened in the short to medium term.

\section{DISCUSSION}

There is no way to predict the future. Historically, one can observe pendular movements of regional control in the Asian theater and around the world. However, prevalent current indicators do not shine a positive light on Japan's ability to once again become a major player in the Asian theater, or globally. In analyzing future potential one must transcend mere economic indicators and look at larger geopolitical and even resource scarcity aspects of the global economy. First and foremost, China's buildup of military 
strength combined with their spending power and innovative Belt and Road Initiative of "linking over 100 countries along a land-based Silk Road Economic Belt (BRI by land), an oceangoing twenty-first century Maritime Silk Road (BRI by sea), and an air-based connection with the Americas (BRI by air), the BRI creates a powerful new wave of globalization - Globalization 5.0"(Gao, 2018, p. 321).

Japan still produces significantly more patents (318,500 in 2017) than other Asian countries, with the exception of China 1.38 million (Tonby et al., 2019). Although contrasted with R\&D spend 3.1 to 2.1 Japan and China, respectively and as a percentage of GDP is not quite as impressive.

According to McKinsey Global Institutes (Tonby et al., 2019), Japanese labor costs are on par with South Korea, Singapore, Australia and New Zealand but are still over four times higher than those in China (USD26.6:6.2). Lastly, looking at China's share of Asia's labor-intensive manufacturing (52\% in 2017) is falling while being picked up by others, such as Vietnam and Indonesia with 7\% and $8 \%$ and growing.

All of this against the background of China's increase in military spending, increasing their military budget by $6.8 \%$ (ChinaPower Project, 2021) to 266 USD bn compared to Japan's 46.6 USD bn, the slow but sure conquest of Hong Kong and their open conquest of additional territory from building islands to, e.g., March 2021 released special report from the Council on Foreign Relations (Blackwill \& Zelikow, 2021), which concluded that Taiwan "is becoming the most dangerous flash point in the world for a possible war" between the United States and China.

There are, however, also mitigating circumstances, such as scarcity of resources (especially peak oil but not rare Earth minerals in which China holds controlling global interests), pollution and climate change.

As stated above, there is no way to predict the future. This is particularly true for Asia where a plethora of factors are pushing towards some new scenario. Whether or not this will represent a balance of power, a framework of cooperation, an equilibrium of power or some nuanced state-of-affairs not falling specifically in any of those categories, only time will tell. Many of the more salient factors contributing to the formation of a new status quo in Asia (and perhaps beyond) are mentioned and described above. All this leads to the conclusion that further research on these dynamic issues is needed.

\section{REFERENCES}

Beeson, M., \& Murray, P. (2020). Testing Times for Regionalism: Coping with Great Power Rivalry in the Asia-Pacific. Asian Studies Review, 44(1), 1-9. https://doi.org/10.1080/10357823.2020.1681052

Blackwill, R. D., \& Zelikow, P. (2021). The United States, China, and Taiwan: A Strategy to Prevent War. In Council on Foreign Relations. Retrieved from https://jstor.proxy.undip.ac.id/stable/resrep28673

Bremmer, I. (2019). The End of the American International Order: What Comes Next? Retrieved November 23, 2019 , from Time website: https://time.com/5730849/end-american-order-what-next/

Caballero-Anthony, M. (2014). Understanding ASEAN's centrality: Bases and prospects in an evolving regional architecture. Pacific Review, 27(4), 563-584. https://doi.org/10.1080/09512748.2014.924227

ChinaPower Project. (2021). What Does China Really Spend on its Military? Retrieved March 19, 2021, from https://chinapower.csis.org/military-spending/

Cohen, B. J. (2007). The transatlantic divide: Why are American and British IPE so different? Review of International Political Economy, 14(2), 197-219. https://doi.org/10.1080/09692290701288277

Deudney, D., \& Ikenberry, G. J. (1999). The Nature and Sources of Liberal International Order. Review of International Studies, 25, 179-196.

Dollar, D., \& Stromseth, J. (2021). US must urgently rethink its economic policies in Asia.

Gao, M. H. (2018). Globalization 5.0 Led by China: Powered by Positive Frames for BRI. In W. Zhang, I. Alon, \& C. Lattemann (Eds.), China's Belt and Road Initiative: Changing the Rules of Globalization (pp. 321-335). https://doi.org/10.1007/978-3-319-75435-2_17

Gilpin, R. (1975). U.S. Power and the Multinational Corporation. New York: Basic Books.

Gilpin, R. (1981). War and Change in World Politics. Retrieved from http://ir.obihiro.ac.jp/dspace/handle/10322/3933 
Gilpin, R. (2001). Global Political Economy: Understanding the International Economic Order. https://doi.org/10.1111/14682508.00006

Harold, S. W. (2015). How Can Japan Improve Relations with South Korea? Asia-Pacific Review, 22(1), 1-24. https://doi.org/10.1080/13439006.2015.1038886

Hui, M. (2021). Japan's rare earths strategy has lessons for US, Europe. Retrieved April 24, 2021, from Quartz website: https://qz.com/1998773/japans-rare-earths-strategy-has-lessons-for-us-europe/

Ikenberry, G. J. (2016). Between the Eagle and the Dragon: America, China, and Middle State Strategies in East Asia. Political Science Quarterly, 131(1), 9-43. https://doi.org/10.1002/polq.12430

Kang, D. C. (2003). Getting Asia Wrong. International Security, 27(4), 57-85.

Kang, D. C. (2007). China Rising. Peace, Power, and Order in East Asia. New York: Columbia University Press.

Kaufman, S. J., Little, R., \& Wohlforth, W. C. (2007). Introduction: Balance and Hierarchy in International Systems. In S. J. Kaufman, R. Little, \& W. C. Wohlforth (Eds.), Balance of Power in World History. https://doi.org/10.1057/9780230591684

Keohane, R. O. (1980). The Theory of Hegemonic Stability and Changes in International Regimes, 1967-1977. In O. R. Holsti, R. M. Siverson, \& A. L. George (Eds.), Change in the International System (pp. 131-162). Boulder: Westview Press.

Keohane, R. O. (1984). After Hegemony. Cooperation and Discord in the World Political Economy. Princeton: Princeton University Press.

Kim, J. (2019). Moon demands Japan drop South Korea export controls. Retrieved March 2, 2021, from Nikkei Asia website: https://asia.nikkei.com/Spotlight/Japan-South-Korea-rift/Moon-demands-Japan-drop-SouthKorea-export-controls

Kindleberger, C. P. (1973). The World in Depression, 1929-39. Berkeley: University of California Press.

Krasner, S. D. (1976). State Power and the Structure of International Trade. World Politics, 28(3), $317-347$. https://doi.org/10.2307/2009974

Lendon, B. (2021). China has built the world's largest navy. Now what's Beijing going to do with it? Retrieved April 26, 2021, from https://edition.cnn.com/2021/03/05/china/china-world-biggest-navy-intl-hnk-mldst/index.html

McGuirk, R. (2021). Australia ends China deals on national interest grounds. Retrieved April 24, 2021, from Canadian Press website: https://ca.news.yahoo.com/australia-ends-chinese-deals-national-114814734.html

Nohara, Y., \& Takeo, Y. (2021). Japan's Exports Jump Most Since 2017 Amid Global Trade Recovery. Retrieved April 24, 2021, from Bloomberg website: https://finance.yahoo.com/news/japan-exports-jump-double-digits000655364.html?soc_src=social-sh\&soc_trk $=\mathrm{ma}$

OECD-WTO. (2021). Trade in value added. https://doi.org/https://doi.org/https://doi.org/10.1787/data-00648en

Pew Research Center. (2016). Hostile Neighbors: China vs. Japan. Retrieved from www.pewresearch.org

Pew Research Center. (2018). Despite Rising Economic Confidence, Japanese See Best Days Bebind Them and Say Children Face a Bleak Future. Retrieved from https://www.pewresearch.org/global/2018/11/12/despite-rising-economicconfidence-japanese-see-best-days-behind-them-and-say-children-face-a-bleak-future/

Snidal, D. (1985). The Limits of Hegemonic Stability Theory. International Organization, 39(4), 579-614.

Stopford, J. M., Strange, S., \& Henley, J. S. (1991). Rival States, Rival Firms. Competition for World Market Shares. Cambridge: Cambridge University Press.

Strange, S. (1987). The Persistent Myth of Lost Hegemony. International Organization, 41(4), 551-574.

Strange, S. (1994). States and Markets. London, New York: Continuum.

Strange, S. (1998). The Retreat of the State. The Diffusion of Power in the World Economy. Cambridge: Cambridge University Press.

Tonby, O., Woetzel, J., Choi, W., Eloot, K., Dhawan, R., Seong, J., \& Wang, P. (2019). The Future of Asia. Asian Flows and Networks are Defining the Next Phase of Globalization.

UNCTAD. (2021a). Foreign direct investment: Inward and outward flows and stock, annual. Retrieved March 13, 2021, from https://unctadstat.unctad.org/wds/TableViewer/tableView.aspx 
UNCTAD. (2021b). UNCTADStat Database. Retrieved February 23, 2021, from https://unctadstat.unctad.org/wds/ReportFolders/reportFolders.aspx?sCS_ChosenLang=en

Yoshimatsu, H. (2021). Japan's Asian Diplomacy. Power Transition, Domestic Politics, and Diffusion of Ideas. Singapore: Palgrave Macmillan.

Zhao, Q. (2004). Japan's Leadership Role in East Asia: Cooperation and Competition between Japan and China. Policy and Society, 23(1), 111-128. https://doi.org/10.1016/S1449-4035(04)70029-6 